\title{
Staphylococcus aureus promoter-lux reporters for drug discovery
}

\author{
Lili R Mesak ${ }^{1,3}$, Shuhua $\mathrm{Qi}^{2,3}$, Ivan Villanueva ${ }^{1}$, Vivian Miao ${ }^{1}$ and Julian Davies ${ }^{1}$ \\ We describe a collection of antibiotic-activated Staphylococcus aureus promoter-lux reporter strains that can be used to \\ discriminate among antibiotic classes on the basis of their light production response profile. We screened over 400 culture \\ supernatants from previously uncharacterized actinomycetes from soil for the production of aminocoumarin-type compounds \\ and DNA-damaging agents. Novobiocin production was determined in three isolates of Streptomyces, and streptonigrin, a \\ DNA-damaging agent, together with several other bioactive compounds (oxopropaline $D$ and $G$ ), was identified from a novel \\ Kitasatospora isolate. This array provides an effective and specific whole-cell approach to search for classes of antimicrobial \\ compounds in unfractionated culture broths.
}

The Journal of Antibiotics (2010) 63, 492-498; doi:10.1038/ja.2010.74; published online 7 July 2010

Keywords: actinomycete; antibiotic profiling/fingerprint; luciferase; promoter-lux reporter; Staphylococcus aureus

\section{INTRODUCTION}

Staphylococcus aureus, a cosmopolitan pathogen isolated from both hospital- and community-acquired infections, causes significant morbidity and mortality (upward of 100000 deaths a year in the United States). ${ }^{1,2}$ Methicillin-resistant $S$. aureus ${ }^{1}$ and vancomycinresistant $S$. aureus ${ }^{3}$ are the most harmful (for reviews see De Leo and Chambers ${ }^{4}$ and Fishbach and Walsh ${ }^{5}$ ), and there is an urgent need for creative screening methods to identify new antimicrobials to treat these infections. ${ }^{5,6}$

It has been argued that the decline in the number of new antimicrobials is due to past emphasis on molecules that were readily detected because they are produced in abundance, and that the supply of such easily accessible, 'low hanging fruit' is close to being exhausted. ${ }^{7}$ A highly sensitive assay for the detection of bioactive compounds at low concentrations would be desirable. Bioluminescent reporters, such as lux, have varous applications, ranging from the detection of specific bacteria in foods ${ }^{8}$ and model infections ${ }^{9,10}$ to the detection of environmental contaminants. ${ }^{11,12}$ These assays are extremely sensitive, accurately reflect real-time changes in gene expression and are well suited for monitoring the activity of promoters on an individual or a genome-wide level. ${ }^{13-16}$
We have used an array of promoter-lux clones in S. aureus for the purpose of detecting low concentrations of bioactive compounds produced by actinomycetes. The approach is based on the observation that almost all antibiotics, at subinhibitory concentrations (sub-MIC), alter the transcription of up to $5 \%$ of genes in bacteria. ${ }^{17}$ This suggested that transcription modulation would provide a sensitive and informative way to test for the presence of biologically active natural products present at low concentrations. ${ }^{14,18}$ Such an array would be extremely useful in natural product screening, when uncharacterized strains are grown on a small scale in generic media; moderately or even poorly productive isolates may be identified in routine fermentation conditions, and an indication of chemical class may be obtained, as transcriptional responses provide characteristic fingerprints. ${ }^{19,20}$

\section{MATERIALS AND METHODS}

Bacterial strains and growth conditions

S. aureus strains (Table 1) were grown at $37^{\circ} \mathrm{C}$ on $\mathrm{NYE}^{21}$ supplemented with chloramphenicol $\left(10 \mu \mathrm{g} \mathrm{m}^{-1}\right)$ (NYEC). S. aureus novobiocin-resistant derivative Nov $^{\mathrm{r}}$ was selected by plating $500 \mu \mathrm{l}$ of a stationary-phase culture of S. aureus RN4220 on NYE medium supplemented with novobiocin

\footnotetext{
${ }^{1}$ Department of Microbiology and Immunology, Life Sciences Institute, University of British Columbia, Vancouver, British Columbia, Canada and ${ }^{2}$ Key Laboratory of Marine Bio-resources Sustainable Utilization/Guangdong Key Laboratory of Marine Materia Medica, South China Sea Institute of Oceanology, The Chinese Academy of Sciences, 164 West Xingang Road, Guangzhou, Guangdong, PR China

3These authors contributed equally to this work.

Correspondence: Dr J Davies, Department of Microbiology and Immunology, Life Sciences Institute, University of British Columbia, 2350 Health Science Mall, Vancouver, British Columbia, Canada V6T 1 Z3.

E-mail: jed@interchange.ubc.ca

It is a pleasure to dedicate this little article to Arnie Demain. However, Arnie deserves more! He has had an enormous impact on streptomycete biology and on the entire antibiotic field. Arnie has written more encyclopedic articles on natural products than anyone I know; these reviews are always extremely useful and are widely quoted. In one respect, Arnie Demain is the self-appointed 'scribe' for the science of antibiotics! Arnie Demain is a fine human being and is one of the nicest people I have ever met; he is always friendly and courteous and I value his friendship enormously.
}

Thank you, Arnie for what you have done for all of us; stay cool!

Most sincerely,

Julian Davies

Received 9 February 2010; revised 9 April 2010; accepted 19 April 2010; published online 7 July 2010 
$\left(5 \mu \mathrm{g} \mathrm{ml}^{-1}\right)$. The MIC for Nov ${ }^{\mathrm{r}}$ was determined in NYE broth: an aliquot of a culture grown overnight from a single colony at $37^{\circ} \mathrm{C}$ was diluted in water at a ratio of $1: 100$, and $10 \mu \mathrm{l}$ was inoculated into $1.5 \mathrm{ml}$ NYE broth in tubes containing novobiocin representing twofold serial dilutions starting from 20

Table $1 \mathrm{~S}$. aureus strains and clones of the promoter-lux array used in this study

\begin{tabular}{|c|c|c|}
\hline Strain & Genotypes & Source \\
\hline RN4220 & Restriction-deficient derivate of $8325-4, \mathrm{rK}^{-} \mathrm{mK}^{+}$ & 49 \\
\hline Cip ${ }^{r} 1$ & $\operatorname{grl} A(\mathrm{Gr} \mid \mathrm{A}(\mathrm{S} 80 \mathrm{~F}))$ & 18 \\
\hline Ciprla & Insertion in norA promoter & 18 \\
\hline Ciprll & $\operatorname{grl} A(\mathrm{Gr} \mid \mathrm{A}(\mathrm{S} 80 \mathrm{Y})), \operatorname{gyr} A(\mathrm{GyrA}(\mathrm{E} 88 \mathrm{~K}))$ & 18 \\
\hline Ciprllb & $\operatorname{grlA}(\operatorname{Gr} \mid A(S 80 Y))$, insertion in norA promoter ${ }^{a}$ & 18 \\
\hline Nov'l & $\operatorname{gyrB}(\mathrm{GyrB}(\mathrm{G} 85 \mathrm{~S}))$ & This study \\
\hline Clone $^{\mathrm{b}}$ & Relevant characteristics (gene/ID promoter-lux) & Source \\
\hline A & tet-lux & 23 \\
\hline B & recA-lux & 18 \\
\hline C & recA-lux & 18 \\
\hline D & recA-lux & 18 \\
\hline $\mathrm{E}$ & recA-lux & 18 \\
\hline $\mathrm{F}$ & recA-lux & 18 \\
\hline G & SAOUHSC_02631-Iuxc & This study \\
\hline $\mathrm{H}$ & SAOUHSC_T0008-lux $x^{a}$ & This study \\
\hline I & SAOUHSC_01895-/ux $x^{a}$ & This study \\
\hline J & SAOUHSC_00545-/Ux ${ }^{a}$ & This study \\
\hline K & SAOUHSC_00535-/ux ${ }^{a}$ & This study \\
\hline $\mathrm{L}$ & SAOUHSC_00007-IUx ${ }^{a}$ & This study \\
\hline M & SAOUHSC_00694-IUX ${ }^{a}$ & This study \\
\hline $\mathrm{N}$ & SAOUHSC_01100-Iuxc & This study \\
\hline
\end{tabular}

aPromoters were cloned into pGYlux.

${ }^{\mathrm{b}} \mathrm{A}, \mathrm{B}$ and $\mathrm{G}$ through $\mathrm{N}$ are in RN4220; C, D, E and F are in Cip ${ }^{r}$ derivatives, Ciprl, Cip ${ }^{r} l a, C^{r} p^{r} I l$ and $\mathrm{Cip}^{\mathrm{r}} \mathrm{Ilb}$, respectively, of RN4200.

cPromoters were cloned into pAmilux. $\mu \mathrm{g} \mathrm{ml}^{-1}$. The MIC value determined after incubation at $37^{\circ} \mathrm{C}$ for $20 \mathrm{~h}$ was $10 \mu \mathrm{g} \mathrm{ml}^{-1}$, or 30-fold higher than that for S. aureus RN4220. The gyrB genes of $\operatorname{Nov}^{\mathrm{r} I}$ and RN4220 were sequenced to identify mutations as described previously. 22

Actinomycete strains named with a 'DCA' prefix were obtained from a collection of microorganisms isolated from lichens, bryophytes and soil in British Columbia. In brief, bacteria were washed from freshly collected materials with $0.001 \%$ Tween and plated on ISP4 agar containing nalidixic acid $\left(20 \mu \mathrm{g} \mathrm{ml}^{-1}\right)$ and the fungicides cycloheximide $\left(50 \mu \mathrm{g} \mathrm{ml}^{-1}\right)$ and benomyl $\left(20 \mu \mathrm{g} \mathrm{ml}^{-1}\right)$. After 7 days at $30^{\circ} \mathrm{C}$, individual colonies were isolated from the plates, purified and deposited into the DCA collection. Strains are not characterized further unless they are flagged as potentially interesting by a screening program. DCA3491 strain was isolated from a lichen sample collected from the University of British Columbia, Malcolm Knapp Research Forest, British Columbia. Reference strain Streptomyces spheroides NRRL 2449 was obtained from the Agricultural Research Collection, United States Department of Agriculture, Peoria, IL.

\section{Construction of the $S$. aureus promoter-lux reporter clones}

Partial Sau3AI digests of $S$. aureus genomic DNA and BamHI-digested PCR amplicons $(0.5-2 \mathrm{~kb})$ of regions upstream of selected $S$. aureus genes were ligated using T4 DNA ligase into pGYlux and pAmilux, replicative E. coli/ S. aureus shuttle plasmids containing a promoterless luxABCDE operon. ${ }^{13}$ The recombinant plasmids were cloned initially in E. coli and then transformed into S. aureus RN4220 or its ciprofloxacin-resistant derivatives $\mathrm{Cip}^{\mathrm{r}} \mathrm{I}, \mathrm{Cip}^{\mathrm{r}} \mathrm{Ia}, \mathrm{Cip}^{\mathrm{r}} \mathrm{II}$, $\mathrm{Cip}^{\mathrm{r}} \mathrm{IIb}$ as described previously. ${ }^{18,23}$ The cloned regions in recombinant strains that exhibited a light response were sequenced. ${ }^{13,18}$

\section{Disk diffusion and lux assays}

A single colony of bioluminescent $S$. aureus from NYEC agar was resuspended in $200 \mu \mathrm{l}$ of sterile water, diluted 1000 -fold into $0.7 \%$ (w/v) agar and overlaid on NYEC plates. Antibiotic disks (Becton Dickinson, Mississauga, ON, Canada; Difco, Detroit, MI, USA) were placed on the overlay and the plates incubated at $37^{\circ} \mathrm{C}$. After $20 \mathrm{~h}$, inhibition zones were measured and luminescence was detected with a luminograph LB980 photon camera (Berthold, Oak Ridge, TN, USA) (for example; see Figure 1).
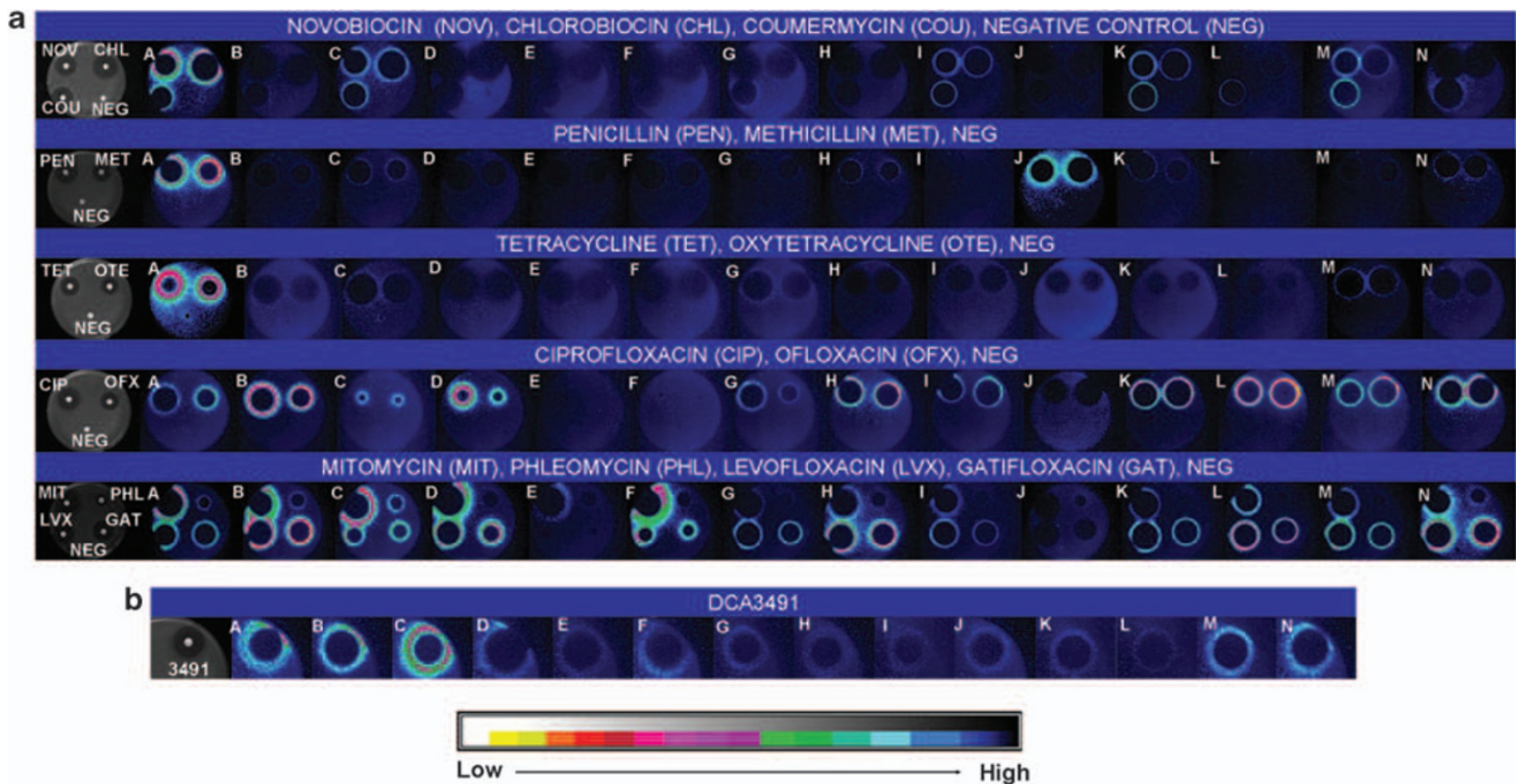

Figure 1 (a) Response of array to antibiotics (b) Response of array to DCA3491 supernatant. Clone name is in the upper left corner of each picture. A clear zone around a disk indicates inhibition of growth in the presence of high levels of antibiotic. At sub-MIC levels (periphery of the zone), changes in luminescence indicate altered transcription. The pseudocolor scale at the bottom indicates relative luminescence. 
Antibiotics used to characterize $S$. aureus clones included cell-membrane damaging agents (daptomycin $30 \mu \mathrm{g}$, polymyxin B $100 \mu \mathrm{g}$ ), cell wall biosynthesis inhibitors (bacitracin $10 \mu \mathrm{g}$, fosfomycin $20 \mu \mathrm{g}$, imipenem $10 \mu \mathrm{g}$, penicillin G $10 \mu \mathrm{g}$, methicillin $10 \mu \mathrm{g}$, vancomycin $30 \mu \mathrm{g}$ ), protein synthesis inhibitors (clindamycin $2 \mu \mathrm{g}$, erythromycin $15 \mu \mathrm{g}$, gentamicin $10 \mu \mathrm{g}$, kanamycin $30 \mu \mathrm{g}$, neomycin $30 \mu \mathrm{g}$, pristinamycin I and II $10 \mu \mathrm{g}$, spectinomycin $100 \mu \mathrm{g}$, streptomycin $10 \mu \mathrm{g}$, tetracycline $30 \mu \mathrm{g}$, oxytetracycline $30 \mu \mathrm{g}$, tobramycin $30 \mu \mathrm{g}$ ), DNA-damaging agents (mitomycin C $5 \mu \mathrm{g}$ and phleomycin $30 \mu \mathrm{g}$ ) and DNA replication inhibitors (ciprofloxacin $5 \mu \mathrm{g}$, ofloxacin $5 \mu \mathrm{g}$, levofloxacin $5 \mu \mathrm{g}$, gatifloxacin $5 \mu \mathrm{g}$, novobiocin $5 \mu \mathrm{g}$, chlorobiocin $5 \mu \mathrm{g}$ and coumermycin $5 \mu \mathrm{g}$ ), a metabolic inhibitor (trimethoprim $5 \mu \mathrm{g}$ ) and an RNA polymerase inhibitor (rifampicin $10 \mu \mathrm{g}$ ). Antibiotics were obtained from Sigma (Oakville, ON, Canada) or from the laboratory collection.

\section{Fermentation and preparation of samples for screening}

Spores and hyphae of actinomycete isolates grown on ISP4 were inoculated into 96-deep-well plates, 24-well plates, $125 \mathrm{ml}$ or 11 flasks containing $1 \mathrm{ml}$ (both types of plates), $30 \mathrm{ml}$ or $250 \mathrm{ml}$ fermentation medium, respectively, and shaken at 200 r.p.m. for 7 days at $30^{\circ} \mathrm{C}$. Medium JR2 was composed of $2.5 \%(\mathrm{w} / \mathrm{v})$ soluble starch, $0.2 \%(\mathrm{w} / \mathrm{v})$ glucose, $0.5 \%(\mathrm{w} / \mathrm{v})$ yeast extract, $0.5 \%(\mathrm{w} / \mathrm{v})$ bacto peptone and $0.3 \%(\mathrm{w} / \mathrm{v}) \mathrm{CaCO}_{3}, \mathrm{pH}$ 7. JR4 was composed of $1 \%(\mathrm{w} / \mathrm{v})$ glucose, $1.5 \%$ glycerol, $1.5 \%(\mathrm{w} / \mathrm{v})$ soya peptone, $0.3 \%(\mathrm{w} / \mathrm{v}) \mathrm{NaCl}, 0.5 \%(\mathrm{w} / \mathrm{v})$ malt extract, $0.5 \%(\mathrm{w} / \mathrm{v})$ yeast extract, $0.1 \%$ tween 80 and $2 \%$ MOPS, pH7. JR11 was composed of $2 \%(\mathrm{w} / \mathrm{v})$ soluble starch, $1 \%(\mathrm{w} / \mathrm{v})$ glucose, $1.5 \%(\mathrm{w} / \mathrm{v})$ soybean meal, $0.5 \%(\mathrm{w} / \mathrm{v})$ peptone and $0.3 \%(\mathrm{w} / \mathrm{v}) \mathrm{CaCO}_{3}, \mathrm{pH}$. Medium JR30 was similar to JR11, but contained $0.25 \%(\mathrm{w} / \mathrm{v})$ animal-free peptone (Millipore Lucratone Pea, Celliance subsidiary of Serologicals Corporation, Milford, MA, USA) instead of $0.5 \%(\mathrm{w} / \mathrm{v})$ peptone. JR2 and JR11 were used in 96-well plate fermentations; JR4 and JR30 were used for fermentation in 24-well plates and flasks. Except for 96-well plates, biomass was removed from cultures by centrifugation and the clarified broth was used directly or stored at $-20^{\circ} \mathrm{C}$. Cultures in 96-well plates were passed through a frit to remove cells, and later through a $>10 \mathrm{kD}$ filter before use.

\section{Thin-layer chromatography (TLC)}

A volume of $1 \mathrm{ml}$ of culture supernatant was extracted with two volumes of EtOAc, and the dried organic phase was dissolved in $50 \mu \mathrm{l} \mathrm{EtOAc.} \mathrm{An} \mathrm{aliquot}$ $(1 \mu \mathrm{l})$ was analyzed by TLC using dichloromethane-methanol-formic acid $(45: 2: 1)^{24}$ and visualized under short ultraviolet light. Novobiocin $(5 \mu \mathrm{g})$ was used as standard.

\section{Structure elucidation}

The culture broth (3.41) of strain DCA3491 in medium JR11 was extracted with EtOAc. The EtOAc extract was concentrated in vacuo to afford $243 \mathrm{mg}$ of residue, which was subjected to column chromatography on Sephadex LH-20 (Amersham Biosciences $\mathrm{AB}$, Uppsala, Sweden) and to elution with $\mathrm{MeOH}$ to yield 19 fractions. The combined fractions (Fr.1, Fr.2-4, Fr 5-9, Fr.10-18 and Fr.19) were used for lux assays and susceptibility tests in S. aureus. Fractions 10-18 contained active compounds and were repeatedly chromatographed over Sephadex LH-20, eluting with $\mathrm{MeOH}$ to yield six subfractions. Active compounds from subfraction 5 were purified by TLC using $\mathrm{CHCl}_{3}-\mathrm{MeOH}$ (9:1) yielding three compounds: compound $1\left(4.1 \mathrm{mg}, R_{F}=0.26\right)$, compound 2 (3.5 mg, $\left.R_{F}=0.54\right)$ and compound $3\left(2.1 \mathrm{mg}, R_{F}=0.74\right) .{ }^{1} \mathrm{H}$ and ${ }^{13} \mathrm{C}$ nuclear magnetic resonance (NMR) spectra of these compounds were recorded on a Bruker AV-400 MHz and AV-600 MHz NMR spectrometer (Bruker Corporation, Billerica, MA, USA) with TMS as internal standard, respectively.

\section{$16 S$ rRNA analysis}

The 16S rRNA gene was amplified from heat-lysed cells of DCA3491 by PCR using primers 7F (5'-GAGAGTTTGATCCTGGCTCAG-3') and 1491R (5'-CGGACTCCTTGTTA-CGACTTC-3') and a program consisting of two cycles at $94^{\circ} \mathrm{C}$ for $15 \mathrm{~s}, 35$ cycles at $94^{\circ} \mathrm{C}$ for $40 \mathrm{~s}, 55^{\circ} \mathrm{C}$ for $1 \mathrm{~min} 30 \mathrm{~s}$ and at $72{ }^{\circ} \mathrm{C}$ for $2 \mathrm{~min}$, and one cycle at $72^{\circ} \mathrm{C}$ for $10 \mathrm{~min}$. The amplicon was sequenced using these or additional primers as needed, and a similarity search was conducted using BLASTN in the NCBI database. The partial $16 \mathrm{~S}$ rRNA gene sequence of DCA3491 (GenBank Accession GU599919) was compared with those of the 23 recognized Kitasatospora species ${ }^{25}$ using alignment and treebuilding functions of MacVector (MacVector, Inc., Cary, NC, USA). Automatically generated alignments were manually adjusted slightly after secondary structure consideration. All available 16S rRNA gene sequence accessions for each Kitasatospora-type strain were assessed, and a best sequence was identified (for example, on the basis of absence of ambiguities or missed bases).

\section{RESULTS}

\section{Development of promoter-lux array}

Two approaches were used to obtain reporter plasmids for the array. An initial shotgun cloning step of a Sau3AI partial digest of S. aureus DNA in E. coli was performed, followed by transformation of individually purified plasmids back into S. aureus RN4220. Of a sample of 35 distinct $S$. aureus transformants obtained in this manner, three luminescent clones were responsive to sub-MIC antibiotics. This showed the feasibility of recovering antibiotic-responsive promoter fragments by random cloning, and more clones were obtained in this manner. In parallel, promoter fragments for recA and lexA genes, ${ }^{18}$ and for other selected genes, ${ }^{18,23}$ were cloned and introduced into S. aureus RN4220 and its ciprofloxacin-resistant $\left(\mathrm{Cip}^{\mathrm{r}}\right)$ derivatives. ${ }^{18,23}$ A total of 53 distinct luminescent promoter-lux-bearing strains (11 from random cloning, 42 with specifically cloned promoters) were tested in disk diffusion assays against a set of 22 antibiotics of different chemical classes and modes of action, and 14 clones with distinct response profiles were finally selected (Table 1).

The light responses can be correlated to a particular class of compounds (Figure 1a). For example; aminocoumarins (novobiocin, chlorobiocin and coumermycin) activated clones A, C, I, K and M, whereas $\beta$-lactam antibiotics (penicillin $G$ and methicillin) activated A and J. Tetracyclines (tetracycline and oxytetracycline) activated only clone A. Fluoroquinolones (ciprofloxacin and ofloxacin) activated all, except E, F and J; it is interesting that the newer fluoroquinolones (levofloxacin and gatifloxacin) also activated F. Two classes of DNAdamaging antibiotics were also tested: mitomycin $\mathrm{C}$ (an aziridine compound) activated all but clone $\mathrm{J}$, whereas phleomycin (a glycopeptide) activated $\mathrm{A}, \mathrm{B}, \mathrm{C}$ and $\mathrm{N}$.

\section{Screening crude culture supernatants}

An initial trial of the array to identify potential hits used a group of six actinomycete strains (DCA2237, DCA2286, DCA2510, DCA2641, DCA2865 and DCA3488), including some suspected to produce novobiocin. Culture supernatants from small-scale fermentations were tested against a subset of five reporter clones: A, B, H, J and K. Supernatants from four strains (DCA2237, DCA2286, DCA2865 and DCA3488) exhibited an aminocoumarin-like profile (only clones A and $\mathrm{K}$ were induced) (Figure 2). Results from subsequent testing of these supernatants, as well as the one obtained from S. spheroides NRRL 2449, a known novobiocin producer, against the full 14-clone array indicated the presence of novobiocin or novobiocin-like compounds (only clones A, $\mathrm{C}, \mathrm{I}, \mathrm{K}$ and $\mathrm{M}$ were induced) (Figure $2 \mathrm{a}$ ). This was consistent with the finding that extracts inhibited growth of $S$. aureus RN4220, but not of $\operatorname{Nov}^{\mathrm{r}} \mathrm{I}$, a novobiocin-resistant derivative carrying a mutation in the $\mathrm{gyr} B$ gene (Tables 1 and 2). TLC analysis of EtOAc extracts of the culture supernatants of DCA2286, DCA2865, DCA3488 and S. spheroides revealed ultraviolet fluorescent spots comigrating with a reference sample of pure novobiocin $\left(R_{F}=0.36 \pm 0.05\right)$ in all extracts (Figure $2 \mathrm{~b}$ ). Metabolites from DCA2237 have been studied elsewhere, and novobiocin was determined to be one of the components. ${ }^{26}$

In another test, 400 culture supernatants obtained by fermentation of 240 newly isolated, uncharacterized actinomycetes in media JR11 and JR2 were investigated. About $17 \%$ of the broths $(22 \%$ of the 


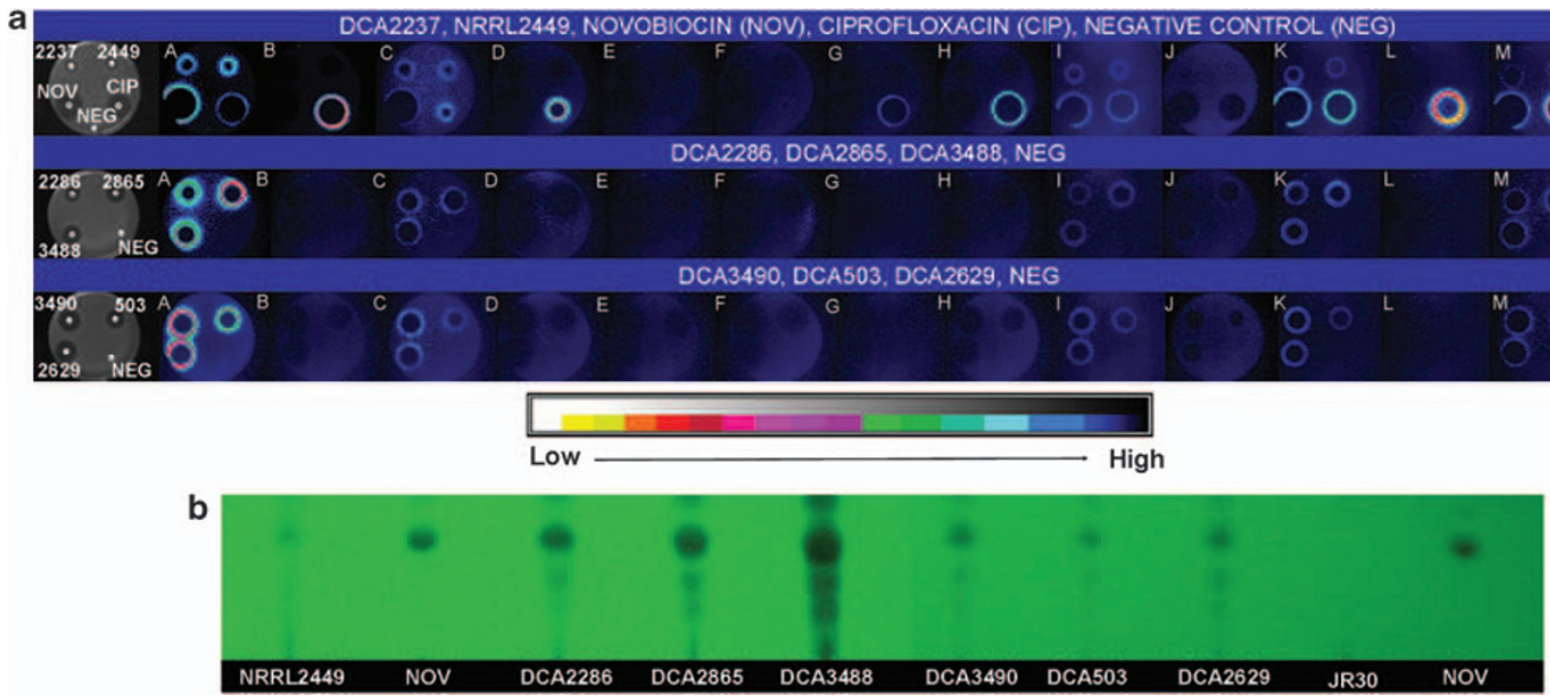

Figure 2 (a) Screening of novobiocin-like compounds. The pseudocolor scale at the bottom indicates relative luminescence. (b) TLC of EtOAc extracts of culture media and novobiocin standard $(5 \mu \mathrm{g})$.

Table 2 Inhibition of S. aureus RN4220 and Nov'l by novobiocin and culture broths

\begin{tabular}{|c|c|c|}
\hline \multirow[b]{2}{*}{ Antibiotic/streptomycete broths } & \multicolumn{2}{|c|}{ Inhibition zone (standard deviation) in $\mathrm{mm}^{\text {a }}$} \\
\hline & S. aureus $R N 4220$ & S. aureus $\mathrm{Nov}^{r} \mathrm{l}$ \\
\hline Novobiocin ( $5 \mu \mathrm{g}$ per disk) & $29(1.9)$ & $12(3.7)$ \\
\hline NRRL2449 (20 ug per disk) & $12(0)$ & 0 \\
\hline DCA2237 $(20 \mu$ l per disk) & $12(0.7)$ & 0 \\
\hline DCA2286 (20 $\mu$ l per disk) & $16(0.9)$ & 0 \\
\hline DCA2865 (20 $\mu$ l per disk) & $20(0.4)$ & 0 \\
\hline DCA3488 (20 $\mu$ l per disk) & $20(0.4)$ & 0 \\
\hline DCA503 (20 $\mu$ l per disk) & $18(2.6)$ & 0 \\
\hline DCA2629 $(20 \mu$ l per disk $)$ & $20(0)$ & 0 \\
\hline DCA3490 $(20 \mu \mathrm{l}$ per disk $)$ & $21(0)$ & 0 \\
\hline
\end{tabular}

aEach experiment was repeated three times.

strains) had some level of inhibitory activity against $S$. aureus. Three strains (DCA503, DCA2629 and DCA3490) were identified as possible novobiocin producers (Figure $2 \mathrm{a}$ ), and subsequent tests showed that their antibiotic activity against $S$. aureus RN4220 was abolished in Nov'r (Table 2). TLC analysis of EtOAc extracts of the culture supernatants from these strains showed spots consistent with authentic novobiocin (Figure 2b). Partial 16S rRNA gene sequences indicated that, even though these strains were isolated from separate environmental samples collected in different years, they were closely related to each other, and to S. spheroides. The $16 \mathrm{~S}$ rRNA gene sequences of DCA503 (1315 nucleotides) and DCA2629 (1314 nucleotides) were identical to that of S. spheroides (Streptomyces caeruleus, GenBank Acc. FJ406110), whereas the gene sequence from DCA3490 (1314 nucleotides) had three conservative ambiguities, but was otherwise also identical to the others. Together, these experiments show that a luxbased screen can be effectively applied to identify bioactive compounds in crude form, and, furthermore, may facilitate dereplication of samples and strains.

\section{Identification of DNA-damaging agents}

As it is known that DNA-damaging agents activate $\operatorname{rec} A,{ }^{18,27,28}$ S. aureus clone B was used to screen the 400 supernatants for these agents. Five percent of the strains activated light responses, and two, DCA3491 and DCA3492, were investigated further. When tested against the complete array, supernatants from these strains activated clones $\mathrm{A}, \mathrm{B}, \mathrm{C}, \mathrm{M}$ and $\mathrm{N}$. This pattern did not correspond to any of the original compounds profiled using the array. The 16S rRNA gene analysis indicated that DCA3491 was a strain of Kitosatospora, with 1435/1446 identities to Kitasatospora atroaurantiaca comb. nov., NRRL B-24282 25 (Figure 3). DCA3492 had the same lux response profiles and was subsequently found to have the same partial $16 \mathrm{~S}$ rRNA sequence as DCA3491.

Fractionation and purification of metabolites from a 3.4-1 culture of DCA3491 in medium JR11 resulted in the identification of three compounds. The ${ }^{1} \mathrm{H}$ and ${ }^{13} \mathrm{C}$ NMR data of the compounds are shown in Table 3.

Compound 1 (dark-brown powder) had the molecular formula of $\mathrm{C}_{25} \mathrm{H}_{22} \mathrm{~N}_{4} \mathrm{O}_{8}$ as deduced from NMR spectra and electrospray ionozation mass spectrum having $m / z 507[\mathrm{M}+\mathrm{H}]^{+}$. Its ${ }^{1} \mathrm{H}$ NMR spectrum suggested the presence of two 1,2,3,4-tetra-substituted benzene rings with signals at $\delta_{\mathrm{H}} 8.36(1 \mathrm{H}, \mathrm{d}, J=11 \mathrm{~Hz}), 9.00(1 \mathrm{H}, \mathrm{d}, J=11.0 \mathrm{~Hz}), 6.73$ $(1 \mathrm{H}, \mathrm{d}, J=9.0 \mathrm{~Hz}), 6.70(1 \mathrm{H}, \mathrm{d}, J=9.0 \mathrm{~Hz})$, three methoxy groups $\left(\delta_{\mathrm{H}} 3.85,3.81,3.75\right.$ (each $\left.\left.3 \mathrm{H}, \mathrm{s}\right)\right)$ and one aromatic methyl $\left(\delta_{\mathrm{H}} 2.17\right.$, $3 \mathrm{H}, \mathrm{s})$. Its ${ }^{13} \mathrm{C}$ NMR spectrum showed the presence of one methyl, three oxymethyls, 18 aromatic carbons between $\delta_{\mathrm{C}} 160$ and $\delta_{\mathrm{C}} 104$, two carbonyl carbons $\left(\delta_{\mathrm{C}} 180.3\right.$ and 176.0) and one carboxyl carbon $\left(\delta_{\mathrm{C}} 167.1\right)$. These ${ }^{1} \mathrm{H}$ and ${ }^{13} \mathrm{C}$ NMR data of compound 1 showed the characteristic signals of streptonigrin. ${ }^{29-31}$ By comparison of mass and ${ }^{1} \mathrm{H}$ and ${ }^{13} \mathrm{C}$ NMR spectral data with published values, compound 1 was identified as streptonigrin.

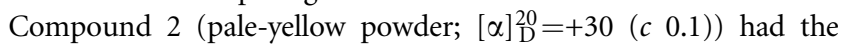
molecular formula of $\mathrm{C}_{15} \mathrm{H}_{14} \mathrm{~N}_{2} \mathrm{O}_{3}$ as deduced from NMR spectra and electrospray ionozation mass spectrum having $m / z 271[\mathrm{M}+\mathrm{H}]^{+}$. Its ${ }^{1} \mathrm{H}$ NMR spectrum suggested the presence of 1,2-disubstituted benzene rings $\left(\delta_{\mathrm{H}} 8.27(1 \mathrm{H}, \mathrm{d}, J=8.0 \mathrm{~Hz}), 7.35(1 \mathrm{H}, \mathrm{dd}, J=8.0,7.0 \mathrm{~Hz})\right.$, $7.61(1 \mathrm{H}, \mathrm{dd}, J=8.2,7.0 \mathrm{~Hz}), 7.74(1 \mathrm{H}, \mathrm{d}, J=8.2 \mathrm{~Hz})$, an aromatic singlet proton $\left(\delta_{\mathrm{H}} 8.30,1 \mathrm{H}, \mathrm{s}\right)$, one aromatic methyl $\left(\delta_{\mathrm{H}} 2.94,3 \mathrm{H}, \mathrm{s}\right)$, one oxymethine $\left(\delta_{\mathrm{H}} 5.59,1 \mathrm{H}, \mathrm{t}, J=4.1 \mathrm{~Hz}\right)$ and one oxymethylene $\left.\left(\delta_{\mathrm{H}} 4.10,1 \mathrm{H}, \mathrm{d}, J=4.1 \mathrm{~Hz}, \mathrm{H}-12\right)\right)$. Its ${ }^{13} \mathrm{C}$ NMR spectrum showed the presence of one methyl, 11 aromatic carbons between $\delta_{\mathrm{C}} 143$ and $\delta_{\mathrm{C}}$ 113 , an $\alpha, \beta$-unsaturated ketone group $\left(\delta_{\mathrm{C}} 202.2\right)$, one oxymethine 


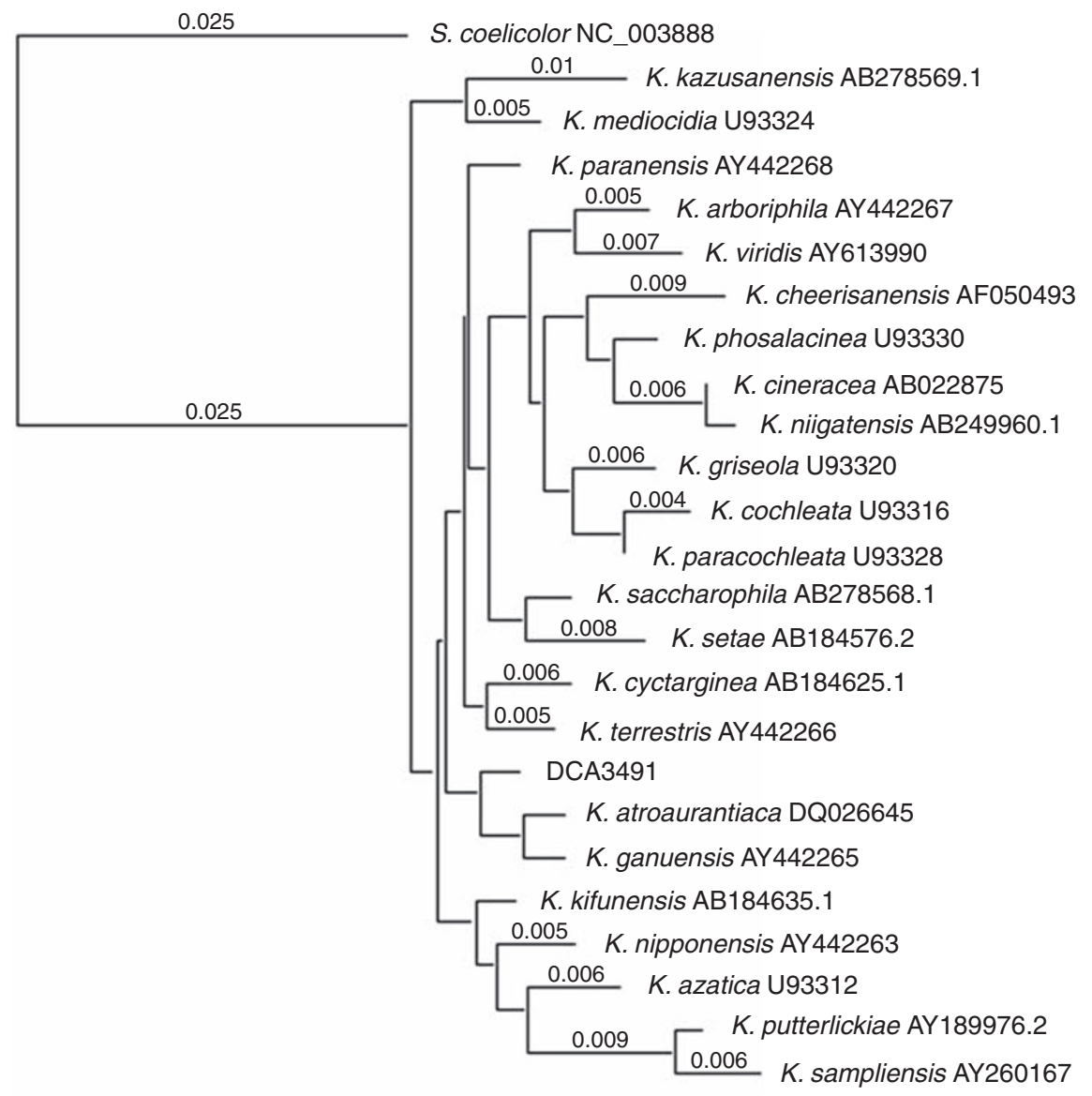

$\stackrel{0.005}{\longmapsto}$

Figure 3 Partial 16S rRNA gene sequence-based dendrogram showing the similarity of DCA3491 and all recognized Kitasatospora species; S. coelicolor was used as an outgroup.

$\left(\delta_{\mathrm{C}} 76.3\right)$ and one oxymethylene $\left(\delta_{\mathrm{C}} 66.1\right)$. These data showed that two had a $\beta$-carboline chromophore. By comparison of mass and ${ }^{1} \mathrm{H}$ and ${ }^{13} \mathrm{C}$ NMR spectral data with published values, ${ }^{32,33}$ compound 2 was identified as oxopropaline $\mathrm{D}$.

Compound 3 (pale-yellow powder, optically inactive) had the molecular formula of $\mathrm{C}_{15} \mathrm{H}_{14} \mathrm{~N}_{2} \mathrm{O}_{2}$ as deduced from NMR spectra and electrospray ionozation mass spectrum having $\mathrm{m} / \mathrm{z}$ $255[\mathrm{M}+\mathrm{H}]^{+}$. Its ${ }^{1} \mathrm{H}$ and ${ }^{13} \mathrm{C}$ NMR spectral data were very similar to those of compound 2 with the only obvious difference that one methylene instead of one oxymethine was observed in compound 3. By comparison of mass and ${ }^{1} \mathrm{H}$ and ${ }^{13} \mathrm{C}$ NMR spectral data with published values, ${ }^{32,33}$ compound 3 was identified as oxopropaline G.

\section{DISCUSSION}

The demand for new antibiotics against resistant and emerging pathogens mandates that innovative antimicrobial screening efforts be increased. ${ }^{34}$ We describe a cell-based $S$. aureus promoter-lux array as a sensitive and predictive method to identify antimicrobials from natural products against $S$. aureus and other bacteria. Similar promoter-lux systems have been used to study the multiple effects of subinhibitory levels of antibiotics, individually or in combination, on gene expression in Salmonella typhimurium and S. aureus; ${ }^{14,17-19,23}$ the sensitive and specific nature of transcription responses to bioactive compounds make them useful as a convenient and robust whole-cell screening system for antimicrobials. The light response readout of a lux-based system has an advantage over firefly luciferase (luc) or

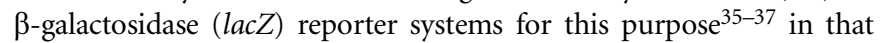
additional substrates are not required for the assay. Promoter-reporters have been used for the discovery of antimicrobials active against Bacillus subtilis ${ }^{20,35,36,38}$ and E. coli, ${ }^{37,39-41}$ but not against S. aureus until now.

The array of $S$. aureus promoter clones used in this study includes 14 bioluminescent $S$. aureus strains carrying promoter-lux constructs ${ }^{23}$ selected for their response to a variety of known antibiotics. Most promoters in the array were obtained after transfer of individual clones of a partial Sau3AI digest library from E. coli into S. aureus because direct cloning into the latter was inefficient and did not result in a sufficiently large number of luminescent clones. ${ }^{21,42}$ Francis et al. $(2000)^{43}$ recovered 73 clones in a different $l u x$ vector with at least moderate luminescence out of $20000 \mathrm{~S}$. aureus transformants, and selected only the six brightest for use in in vivo tracking. In our study, 53 luminescent clones were generated. We included a combination of selectively cloned (recA, tet) and randomly cloned/functionally selected promoters to provide a broader base for the array. The response profiles of promoter-lux plasmids are affected by host backgrounds; for example, recA-lux plasmids in S. aureus RN4220 and Cip ${ }^{\mathrm{r}}$ mutants respond differently to DNA-damaging agents, novobiocin and rifampcin. ${ }^{18}$ Combining reporter plasmids and specific antibiotic resistances in the host expands the screening range, and can exclude 
Table $3{ }^{1} \mathrm{H}(400 \mathrm{MHz})$ and ${ }^{13} \mathrm{C}(150 \mathrm{MHz})$ NMR data for compounds $1-3$

\begin{tabular}{|c|c|c|c|c|c|c|}
\hline \multirow[b]{2}{*}{ Position } & \multicolumn{2}{|c|}{1} & \multicolumn{2}{|c|}{2} & \multicolumn{2}{|c|}{3} \\
\hline & ${ }^{1} H$ & ${ }^{13} \mathrm{C}$ & ${ }^{1} H$ & ${ }^{13} \mathrm{C}$ & ${ }^{1} H$ & ${ }^{13} \mathrm{C}$ \\
\hline 1 & & & & $134.8 \mathrm{C}$ & & $135.5 \mathrm{C}$ \\
\hline 2 & & $159.9 \mathrm{C}$ & & & & \\
\hline 3 & $9.00(\mathrm{~d}, 11.0)$ & $125.9 \mathrm{CH}$ & $8.30(\mathrm{~s})$ & $140.0 \mathrm{CH}$ & $8.26(\mathrm{~s})$ & $139.8 \mathrm{CH}$ \\
\hline 4 & $8.36(d, 11)$ & $133.4 \mathrm{CH}$ & & $134.8 \mathrm{C}$ & & $134.1 \mathrm{C}$ \\
\hline $4 a$ & & $126.7 \mathrm{C}$ & & $131.4 \mathrm{C}$ & & $131.3 \mathrm{C}$ \\
\hline $4 b$ & & & & $122.0 \mathrm{C}$ & & $122.3 \mathrm{C}$ \\
\hline 5 & & $176.0 \mathrm{C}$ & $8.27(\mathrm{~d}, 8.0)$ & $124.7 \mathrm{CH}$ & $8.25(\mathrm{~d}, 8.0)$ & $124.5 \mathrm{CH}$ \\
\hline 6 & & $135.8 \mathrm{C}$ & $7.35(\mathrm{dd}, 8.0,7.0)$ & $122.3 \mathrm{CH}$ & $7.34(\mathrm{dd}, 8.0,7.0)$ & $121.8 \mathrm{CH}$ \\
\hline 7 & & $141.6 \mathrm{C}$ & $7.61(\mathrm{dd}, 8.2,7.0)$ & $129.9 \mathrm{CH}$ & $7.59(\mathrm{dd}, 7.0,7.0)$ & $129.7 \mathrm{CH}$ \\
\hline 8 & & $180.3 \mathrm{C}$ & $7.74(\mathrm{~d}, 8.2)$ & $113.6 \mathrm{CH}$ & $7.72(\mathrm{~d}, 7.0)$ & $113.5 \mathrm{CH}$ \\
\hline $8 a$ & & $144.2 \mathrm{C}$ & & $143.4 \mathrm{C}$ & & $143.4 \mathrm{C}$ \\
\hline 9 & 3.81 (s) & $59.8 \mathrm{CH}_{3}$ & & $127.4 \mathrm{CH}$ & & $127.4 \mathrm{CH}$ \\
\hline $9 a$ & & & & $136.5 \mathrm{C}$ & & $136.2 \mathrm{C}$ \\
\hline 10 & & & & 202.2 C & & 203.3 C \\
\hline 11 & & & $5.59(t, 4.1)$ & $76.3 \mathrm{CH}$ & $3.54(t, 6.2)$ & $41.9 \mathrm{CH}_{2}$ \\
\hline 12 & & & $4.10(d, 4.1)$ & $66.1 \mathrm{CH}_{2}$ & $4.08(t, 6.2)$ & $66.1 \mathrm{CH}_{2}$ \\
\hline 13 & & & $2.94(\mathrm{~s})$ & $17.8 \mathrm{CH}_{3}$ & $2.92(\mathrm{~s})$ & $18.0 \mathrm{CH}_{3}$ \\
\hline $2^{\prime}$ & & $134.0 \mathrm{C}$ & & & & \\
\hline $3^{\prime}$ & & $136.9 \mathrm{C}$ & & & & \\
\hline $4^{\prime}$ & & $134.6 \mathrm{C}$ & & & & \\
\hline $5^{\prime}$ & & $145.7 \mathrm{C}$ & & & & \\
\hline $6^{\prime}$ & & $129.6 \mathrm{C}$ & & & & \\
\hline $7^{\prime}$ & $2.17(\mathrm{~s})$ & $17.0 \mathrm{CH}_{3}$ & & & & \\
\hline $8^{\prime}$ & & $167.1 \mathrm{C}$ & & & & \\
\hline $1 "$ & & $114.9 \mathrm{C}$ & & & & \\
\hline 2" & & $148.1 \mathrm{C}$ & & & & \\
\hline 3" & & $136.2 \mathrm{C}$ & & & & \\
\hline 4" & & $153.1 \mathrm{C}$ & & & & \\
\hline 5" & $6.70(\mathrm{~d}, 9.0)$ & $104.4 \mathrm{CH}$ & & & & \\
\hline 6" & $6.73(d, 9.0)$ & $124.7 \mathrm{CH}$ & & & & \\
\hline 7" & $3.85(\mathrm{~s})$ & $60.3 \mathrm{CH}_{3}$ & & & & \\
\hline $8 "$ & $3.85(\mathrm{~s})$ & $55.7 \mathrm{CH}_{3}$ & & & & \\
\hline $\mathrm{NH} 2$ & $6.90(\mathrm{~s})$ & $134.8 \mathrm{CH}$ & & $134.8 \mathrm{CH}$ & & $134.8 \mathrm{CH}$ \\
\hline $\mathrm{OH}$ & 8.90 (s) & $32.7 \mathrm{CH}_{2}$ & & $32.7 \mathrm{CH}_{2}$ & & $32.7 \mathrm{CH}_{2}$ \\
\hline
\end{tabular}

Compounds 1-3 were determined in DMSO- $d 6, \mathrm{CD}_{3} \mathrm{OD}$ and $\mathrm{CD}_{3} \mathrm{OD}$, respectively; chemical-shift values $\delta$ were in ppm and coupling constant values $J$ in $\mathrm{Hz}$.

detection of commonly found antibiotics in the same screen. Clones not used in the current array remain a resource for the future, as they may give distinctive responses to new compounds added to expand the capabilities of the array. Promoters identified through recent microarray-based studies ${ }^{27,44-47}$ of transcriptional changes in S. aureus in response to sub-MIC antibiotics may be other candidates for inclusion.

Exposure of the array to bioactive compounds elicits a response from each clone, with the set of responses forming a characteristic profile or fingerprint for that source: potentially new compounds are consequently highlighted by novel profiles. The ability to use crude broths, a key consideration during the development of the array, makes it an economical and robust assay with high information value that can be applied at the earliest stages of a natural product screening program. We identified potential novobiocin producers among 240 uncharacterized strains in a single screen using only crude broth, allowing efficient execution of confirmation studies (TLC and inhibition assays against $\operatorname{Nov}^{r} 1$ ). This showed the value of $l u x$ array, not only for early elimination of known compounds but also for dereplication of duplicate strains.
The screening array is valuable for the prioritization of hit candidates and amenable to customization by including clones that recognize additional antibiotics or classes of antibiotics based on structure or mode of action, such as clones that respond to macrolides and aminoglycosides, as well as those that distinguish among structural classes of DNA-damaging agents. Streptonigrin, an antitumor agent discovered in Streptomyces flocculus, ${ }^{48}$ has been observed in Micromonospora sp. ${ }^{31}$ and oxopropalines D and G have been reported from microorganisms, such as Streptomyces sp. G324. ${ }^{33}$ The producing strain, Kitasatospora sp. DCA3491, is a distinct taxon from Kitasatospora sp. MJM383, a strain that was also recently reported to produce streptonigrin and oxopropaline G. ${ }^{30}$ The latter strain was noted as being most similar to K. azatica, and belongs to a different clade. ${ }^{30}$

In conclusion, we have used the sensitive and specific relationships between antibiotics and transcription modulation in bacteria to develop a promoter-reporter-based $S$. aureus array for screening bioactive compounds in crude broths from microbial fermentations. Additional combinations of host strains and promoter-lux constructs, including downstream promoters, will expand the screening potential in the future. 


\section{ACKNOWLEDGEMENTS}

This research was supported by CIHR (Canadian Institutes of Health Research). We thank Joo Won Suh (Myongji University, Korea) for sharing information. We acknowledge Hao Wang, Lorena Plastino, Terry Taylor, Natalia Subrt (University of British Columbia, Canada), and Dana Yu and Richard Dean (Centre for Drug Research and Development, Canada) for their contributions to our work.

1 Gordon, R. J. \& Lowy, F. D. Pathogenesis of methicillin-resistant Staphylococcus aureus infection. Clin. Infect. Dis. (46 Suppl 5), S350-359 (2008).

2 Levy, S. B. \& Marshall, B. Antibacterial resistance worldwide: causes, challenges and responses. Nat. Med. 10, S122-129 (2004).

3 Sievert, D. M. et al. Vancomycin-resistant Staphylococcus aureus in the United States, 2002-2006. Clin. Infect. Dis. 46, 668-674 (2008).

4 DeLeo, F. R. \& Chambers, H. F. Reemergence of antibiotic-resistant Staphylococcus aureus in the genomics era. J. Clin. Invest. 119, 2464-2474 (2009).

5 Fischbach, M. A. \& Walsh, C. T. Antibiotics for emerging pathogens. Science. 325, 1089-1093 (2009).

6 Projan, S. J. \& Youngman, P. J. Antimicrobials: new solutions badly needed. Curr. Opin. Microbiol. 5, 463-465 (2002).

7 Baltz, R. H. Marcel Faber Roundtable: is our antibiotic pipeline unproductive because of starvation, constipation or lack of inspiration? J. Ind. Microbiol. Biotechnol. 33, 507-513 (2006).

8 Loessner, M. J., Rudolf, M. \& Scherer, S. Evaluation of luciferase reporter bacteriophage $A 511:$ luxAB for detection of Listeria monocytogenes in contaminated foods. Appl. Environ. Microbiol. 63, 2961-2965 (1997).

9 Kadurugamuwa, J. L. et al. Direct continuous method for monitoring biofilm infection in a mouse model. Infect. Immun. 71, 882-890 (2003).

10 Kadurugamuwa, J. L. et al. Rapid direct method for monitoring antibiotics in a mouse model of bacterial biofilm infection. Antimicrob. Agents Chemother. 47, 3130-3137 (2003).

11 Ptitsyn, L. R. et al. A biosensor for environmental genotoxin screening based on an SOS Iux assay in recombinant Escherichia coli cells. Appl. Environ. Microbiol. 63, 4377-4384 (1997).

12 Sanseverino, J. et al. Use of Saccharomyces cerevisiae BLYES expressing bacterial bioluminescence for rapid, sensitive detection of estrogenic compounds. Appl. Environ. Microbiol. 71, 4455-4460 (2005).

13 Mesak, L. R., Yim, G. \& Davies, J. Improved lux reporters for use in Staphylococcus aureus. Plasmid 61, 182-187 (2009).

14 Goh, E. B. et al. Transcriptional modulation of bacterial gene expression by subinhibitory concentrations of antibiotics. Proc. Natl Acad. Sci. USA 99, 17025-17030 (2002).

15 Bjarnason, J., Southward, C. M. \& Surette, M. G. Genomic profiling of iron-responsive genes in Salmonella enterica serovar typhimurium by high-throughput screening of a random promoter library. J. Bacteriol. 185, 4973-4982 (2003).

16 Van Dyk, T. K., DeRose, E. J. \& Gonye, G. E. LuxArray, a high-density, genomewide transcription analysis of Escherichia coli using bioluminescent reporter strains. J. Bacteriol. 183, 5496-5505 (2001).

17 Yim, G., de la Cruz, F., Spiegelman, G. B. \& Davies, J. Transcription modulation of Salmonella enterica serovar Typhimurium promoters by sub-MIC levels of rifampin. J. Bacteriol. 188, 7988-7991 (2006).

18 Mesak, L. R., Miao, V. \& Davies, J. Effects of subinhibitory concentrations of antibiotics on SOS and DNA repair gene expression in Staphylococcus aureus. Antimicrob. Agents Chemother. 52, 3394-3397 (2008).

19 Tsui, W. H. et al. Dual effects of MLS antibiotics: transcriptional modulation and interactions on the ribosome. Chem. Biol. 11, 1307-1316 (2004).

20 Hutter, B. et al. Prediction of mechanisms of action of antibacterial compounds by gene expression profiling. Antimicrob. Agents Chemother. 48, 2838-2844 (2004).

21 Schenk, S. \& Laddaga, R. A. Improved method for electroporation of Staphylococcus aureus. FEMS Microbiol Lett. 73, 133-138 (1992).

22 Fujimoto-Nakamura, M., Ito, H., Oyamada, Y., Nishino, T. \& Yamagishi, J. Accumulation of mutations in both gyrB and parE genes is associated with high-level resistance to novobiocin in Staphylococcus aureus. Antimicrob. Agents Chemother. 49, 3810-3815 (2005)
23 Mesak, L. R. \& Davies, J. Phenotypic changes in ciprofloxacin-resistant Staphylococcus aureus. Res. Microbiol. 160, 785-791 (2009).

24 Wang, Z. X., Li, S. M. \& Heide, L. Identification of the coumermycin A(1) biosynthetic gene cluster of Streptomyces rishiriensis DSM 40489. Antimicrob. Agents Chemother. 44, 3040-3048 (2000).

$25 \mathrm{Li}$, B., Furihata, K., Kudo, T. \& Yokota, A. Kitasatospora saccharophila sp. nov. and Kitasatospora kazusanensis sp. nov., isolated from soil and transfer of Streptomyces atroaurantiacus to the genus Kitasatospora as Kitasatospora atroaurantiaca comb. nov. J. Gen. Appl. Microbiol. 55, 19-26 (2009).

26 Cheenpracha, S. et al. Coumabiocins A-F, Aminocoumarins from an organic extract of Streptomyces sp. L-4-4. J. Nat. Prod. 73, 880-884 (2010).

27 Anderson, K. L. et al. Characterization of the Staphylococcus aureus heat shock, cold shock, stringent, and SOS responses and their effects on log-phase mRNA turnover. J. Bacteriol. 188, 6739-6756 (2006).

28 Cirz, R. T. et al. Complete and SOS-mediated response of Staphylococcus aureus to the antibiotic ciprofloxacin. J. Bacteriol. 189, 531-539 (2007).

29 Rao, K. V. \& Cullen, W. P. Streptonigrin, an antitumor substance. I. Isolation and characterization. Antibiot. Annu. 7, 950-953 (1959).

$30 \mathrm{Jin}, \mathrm{Y}$. Y. et al. Kitasatospora sp. MJM383 strain producing two antitumor agents, streptonigrin and oxopropaline G. J. Microbiol. Biotechnol. 15, 1140-1145 (2005).

31 Wang, H. et al. Isolation of streptonigrin and its novel derivative from Micromonospora as inducing agents of p53-dependent cell apoptosis. J. Nat. Prod. 65, 721-724 (2002).

32 Abe, N. et al. Novel cytocidal compounds, oxopropalines from Streptomyces sp. G324 producing lavendamycin. II. Physico-chemical properties and structure elucidations. J. Antibiot. (Tokyo) 46, 1678-1686 (1993).

33 Abe, N. et al. Novel cytocidal compounds, oxopropalines from Streptomyces sp. G324 producing lavendamycin. I. Taxonomy of the producing organism, fermentation, isolation and biological activities. J. Antibiot. (Tokyo) 46, 1672-1677 (1993).

34 Vicente, M. et al. The fallacies of hope: will we discover new antibiotics to combat pathogenic bacteria in time? FEMS Microbiol. Rev. 30, 841-852 (2006).

35 Hutter, B., Fischer, C., Jacobi, A., Schaab, C. \& Loferer, H. Panel of Bacillus subtilis reporter strains indicative of various modes of action. Antimicrob. Agents Chemother. 48, 2588-2594 (2004).

36 Urban, A. et al. Novel whole-cell antibiotic biosensors for compound discovery. Appl. Environ. Microbiol. 73, 6436-6443 (2007).

37 Shapiro, E. \& Baneyx, F. Stress-activated bioluminescent Escherichia coli sensors for antimicrobial agents detection. J. Biotechnol. 132, 487-493 (2007).

38 Fischer, H. P. et al. Identification of antibiotic stress-inducible promoters: a systematic approach to novel pathway-specific reporter assays for antibacterial drug discovery. Genome Res. 14, 90-98 (2004).

39 Oyamada, Y. et al. A nucleate cell blue assay: a useful tool for identifying novel type II topoisomerase inhibitors. Antimicrob. Agents Chemother. 50, 348-350 (2006).

40 Bianchi, A. A. \& Baneyx, F. Stress responses as a tool to detect and characterize the mode of action of antibacterial agents. Appl. Environ. Microbiol. 65, 5023-5027 (1999).

41 Shapiro, E. \& Baneyx, F. Stress-based identification and classification of antibacterial agents: second-generation Escherichia coli reporter strains and optimization of detection. Antimicrob. Agents Chemother. 46, 2490-2497 (2002).

42 Kraemer, G. R. \& Iandolo, J. J. High-frequency transformation of Staphylococcus aureus by electroporation. Curr. Microbiol. 21, 373-376 (1990).

43 Francis, K. P. et al. Monitoring bioluminescent Staphylococcus aureus infections in living mice using a novel I I $A B B C D E$ construct. Infect. Immun. 68, 3594-3600 (2000).

44 Chang, W., Small, D. A., Toghrol, F. \& Bentley, W. E. Global transcriptome analysis of Staphylococcus aureus response to hydrogen peroxide. J. Bacteriol. 188, 1648-1659 (2006).

45 Utaida, S. et al. Genome-wide transcriptional profiling of the response of Staphylococcus aureus to cell-wall-active antibiotics reveals a cell-wall-stress stimulon. Microbiology 149, 2719-2732 (2003).

46 Pietiainen, M. et al. Transcriptome analysis of the responses of Staphylococcus aureus to antimicrobial peptides and characterization of the roles of $v r a D E$ and $v r a S R$ in antimicrobial resistance. BMC. Genomics 10, 429 (2009).

47 Wang, D. et al. Global transcriptional profiles of Staphylococcus aureus treated with berberine chloride. FEMS Microbiol. Lett. 279, 217-225 (2008).

48 Bolzan, A. D. \& Bianchi, M. S. Genotoxicity of streptonigrin: a review. Mutat. Res. 488 , 25-37 (2001)

49 Kreiswirth, B. N. et al. The toxic shock syndrome exotoxin structural gene is not detectably transmitted by a prophage. Nature. 305, 709-712 (1983). 